\title{
The right to diversity in the route of interculturality in the school curriculum
}

\author{
Ana Maria Eyng ${ }^{a}$ \\ Glaucio Luiz Mota ${ }^{b}$ \\ Mônica Luiza Simião Pinto ${ }^{c}$ \\ Cleumir Sehn ${ }^{d}$
}

\section{Resumo}

In this text, we discuss the right to diversity in the curriculum, considering it as a course of identity formation and guarantee of rights, through practices that dialogue with equality and difference through interculturality. The dialectical method is based on the establishment of the dialogical relationship among traces of theoretical studies, public policies and perceptions of curriculum subjects in the perspective of cultural studies. With this in mind, we bring together the voices of students and teachers on one of the traces of diversity, the religiosity. Historically, it is about a theme that has been the source of fierce disputes, even if the purpose of that debate was conciliation. The results point out to the permanence of the challenge of implementing the right to diversity in the curriculum, whose overcoming requires a fight for democratic principles with the support of interculturality, which can promote participation and recognition of equality and difference. Therefore, the right to diversity requires the practice of a type of pedagogy which favors access to borders in the challenged terrain of the curriculum, through fair cultural negotiations.

Keywords: Curriculum. Cultural diversity. Interculturality. Guarantee of rights. Basic education.

\footnotetext{
a Pontifícia Universidade Católica do Paraná. Curitiba, Paraná, Brasil.

b Pontifícia Universidade Católica do Paraná. Curitiba, Paraná, Brasil.

c Instituto Federal do Paraná. Curitiba, Paraná, Brasil.

d Pontifícia Universidade Católica do Paraná. Curitiba, Paraná, Brasil. 


\section{Introdução}

The contemporary context of which schools are a part demonstrates aspects of a troubled society, where assumptions, values, and principles aligned to modern and neoliberal thought prevail, reproducing exclusive and unequal relationships. In this study, we discuss diversity ${ }^{1}$ on the curriculum, understanding it as a place and route to guarantee rights, through practices that engage in a dialogue of interculturality. "This supposes democratic relations, interculturally oriented curricula, dialoguing with diversity as a way to overcome the standardization based on prejudice and inequality" (EYNG et al., 2013, p. 778). To this end, knowledge positions and ethical actions that recognize and value cultural differences, as distinct expressions of ways of signification, being, thinking, and acting, are required. "However, it is possible to observe that teachers are still based predominantly on conceptions that make it difficult to overcome educational practices that affirm the homogeneity of subjects and educational contexts" (EYNG et al., p. 794).

On that note, the reflection is based on arguments that aim to answer the following question: can the curriculum guarantee the right to diversity as an expression of interculturality? To answer this question, we delimit the study on the cultural differences in the school context, with focus on the religiosity that pervades the curricular routes of the subjects in the school to exemplify traces of diversity. Individuals' perceptions are extracted from empirical research with contributions from 15 teachers and 54 students of basic education.

From this data, having the Cultural Studies ${ }^{2}$ as the basis for data analysis, we chose the analytical categories indicated by Giroux (1999): language, difference, curriculum (as contested territory) and pedagogy (as culture), which will point to the need of interculturality.

This analytical movement of research based on Cultural Studies is based on the dialectical method for describing conceptions about diversity in the curriculum. It also establishes the dialogical relationship among traits of contributions from theoretical studies, educational policy contributions, and contributions of traits

\footnotetext{
Para Bhabha (2013): Cultural diversity is an epistemological object - the culture as an object of empirical knowledge - while cultural difference is the process of enunciation of culture as "knowable," legitimate, and appropriate to the construction of systems of cultural identification. If diversity is a category of ethics, aesthetics, or ethnological comparison, cultural difference is a meaning process through which affirmations of the culture, or the culture itself, differentiate, discriminate, and authorize the production of fields of force, reference, applicability, and capacity (BHABHA, 2013, p. 69). In this sense, we have determined that the right to diversity is an epistemological starting point for considering the statements of cultural identities and differences.

2 Para Marisa Vorraber Costa, Wortmann e Bonin: "[...] observa-se nos Estudos Culturais em Educação, e não só naqueles realizados no Brasil, uma oscilação por entre tendências teóricas, perceptível em variadas tentativas de aglutinar conceitos críticos e pós-críticos" (2016, p. 512).
} 
from students and teachers' perceptions about the religiosity of the subjects in the curriculum.

Theoretical contributions were taken from critical and post-critical literature on curricula, and studies on the modern and post-modern context and interculturality, among which we have used Arroyo (2012), Bhabha (2013), Candau (2012), Eyng (2010; 2013), Macedo (2006; 2013), TORRES Santomé (2013), Santos (2010), and Silva $(2010 ; 2014 ; 2015)$.

Policy contributions are derived from international documents, in particular the Universal Declaration of Human Rights (ONU, 1948), the UNESCO Convention against Discrimination in Education (UNESCO, 1960), the World Conference on Human Rights (ONU, 1993), the Decade of Education on Human Rights (UNESCO, 1994), and the World Program for Education on Human Rights (UNESCO, 2006), as well as on national policies in Brazil, such as the National Plan for Education on Human Rights (BRASIL, 2007), the National Program on Human Rights (BRASIL, 2010), and CNE Report 08/2012 on the National Guidelines for Education on Human Rights (BRASIL, 2012).

The right to diversity emerges from cultural policies in the curriculum based on the trajectory of human rights and educational policies. However, the translations of these policies reflect interests and are circumscribed by power games that demand a political position of resistance, able to counter interests that tend to deepen social inequalities and increase the need for a struggle for the guarantee of rights. In this direction, in the article we present intercultural possibilities that consider the fight for the right to diversity in the field of the curriculum. Thus, we begin the debate with the understanding that diversity is a human right to be understood and guaranteed in the trajectories of the curriculum.

\section{The rights to diversity in the curricular policies and practices}

Human rights have historically been created based on political, social, cultural, and economic influences, in addition to the individual and collective needs of each period. They can be understood "in a simpler way, as socially recognized practices, of struggles for human dignity” (ESTEVÃO, 2013, p. 14). The struggle to guarantee rights has been defined in terms of generations (BOBBIO, 2004) or dimensions (BONAVIDES, 2008) which reaffirm their historicity and dynamism. 
First-generation rights, which relate to freedom, have been materialized in civil rights in the form of privacy, freedom of movement, expression, and the press; they also apply to freedom of religion. The right to liberty refers to the adoption of a liberal vision, which implies freedom of action and expression of the individual and a "non-action of the State" (BOBBIO, 2004, p. 9). The affirmation of firstgeneration rights emphasized the absence of other dimensions of rights, such as political and social rights (CULLETON; BRAGATO; FAJARDO, 2009). Since the 19th century, second-generation rights, related to equality, have been affirmed, as represented in political rights (political participation, association, and voting rights) and expanded in the 20th century in terms of social rights (education, labor rights, security, health). Third-generation rights, related to solidarity, include the right to a family, cultural identity, and self-determination, the rights of ethnic and religious minorities, and the right to live in a pollution-free and sustainable environment (BOBBIO, 2004). Fourth-generation rights emphasize issues such as bioethics and bio-law, the right to life, and other topics arising from questions on the manipulation of human life and other living beings (BOBBIO, 2004, p. 9). Bonavides (2008) discusses fifth-generation rights, the right to peace, recognizing in the social panorama the affirmation of rights related to the subject of difference.

Within this context, the right to equality - which confuses itself with standard practices and homogenization - is incorporated and consolidated in the school context,. However, the right to difference still has a long way to come to be in fact incorporated in the school curricula, although it is widely affirmed in school policies and human rights.

Therefore, the rights to equality and difference are present throughout history, mobilizing the struggles for affirmation and guarantee of rights. These struggles have produced a set of documents, statements, and international conventions, which have influenced the political documents of the signatory nations and are being gradually incorporated into policies and school practices.

In the contemporary perspective, our main guiding document is the Universal Declaration of Human Rights (ONU, 1948), a milestone for Eastern societies in the equality of rights between men and women, as well as the right to freedom of beliefs and cultures. Its article XVIII states: "Every human being has the right to freedom of thought, conscience and religion; this right includes the freedom to change religion or belief and the freedom to express that religion or belief, by teaching, practicing, worshiping and observing, in public or private" (ONU, 1948). 
The Declaration made on Article XXVI strengthens the role of education (instruction) in promoting the right to "understanding, tolerance and friendship among all Nations and racial or religious groups" (ONU, 1948). In this sense, the right to equality and difference is a fundamental principle of educational practices, in terms of overcoming inequalities, exclusions, discrimination, and all forms of violation of rights. Education is thus called upon to adopt a new attitude towards inequality and to overcome exclusionary practices.

The World Conference on Human Rights (ONU, 1993) also affirms the equality of minority groups, to enjoy "their own culture, to profess and practice their religion and to express themselves in their language, both in private and public, freely and without interference or any form of discrimination" (ONU, 1993, N. 19). It emphasizes the indispensable role of education in promoting friendly relationships among nations and racial or religious groups, through the inclusion of educational programs on human rights (ONU, 1993).

In this sense, the Decade of Education (1995-2004) enabled debate expansion and created a space for the development of educational proposals which claim, guarantee, and protect the rights to equality and difference (ONU, 1993). Education on human rights has emerged as an instrument for information dissemination and the capacity to create a culture of rights, to defend the dignity and respect inherent to all members of society, through equal opportunities, inclusion of diversity, and non-discrimination, as through the World Program for Education on Human Rights (UNESCO, 2006).

These international guidelines have been incorporated into several Brazilian national policies, for example, the National Program on Human Rights (PNDH-3), which addresses equality and difference as fundamental aspects of the fight against inequality, in its "guarantee of equality in diversity" (BRASIL, 2010).

The National Plan for Education on Human Rights (BRASIL, 2007) considers the promotion, protection, and defense of rights through the countersigned Education on Human Rights:

[...] on cultural and environmental diversity, guaranteeing citizenship, access to education, permanence and conclusion, equity (racial-ethnic, religious, cultural, territorial, physical-individual, generational, of gender, sexual orientation, political option, nationality, among others) and the quality of education (BRASIL, 2007). 
Equality and difference underlie the Report of the National Guidelines for Education on Human Rights (BRASIL, 2012), recognizing "the issue of diversity of groups and individuals historically excluded from the right to education and, more generally, from other rights" (BRASIL, 2012, p. 8).

Although human rights policies contribute to equality and difference being respected, valued, and protected, the challenges pertaining to coexistence among people, including individuals in educational institutions, remain enormous. These challenges have become evident in recent years in disputes that have increased the incidence of terrorism, massacres, and all forms of violence and intolerance toward cultural differences.

Although the contemporary approach to culture has sought to consider the diversity that emerges from subjects, contexts, groups and institutions, most government policies are still aligned with market interests and there are attempts to control diversity. In this sense, we agree with Veiga-Neto (2003) and reaffirm the need to step away from the idea of a universalizing culture toward an approach that considers diverse and different cultures. This means not only monocultural predominance, but also the point of view of diversity, especially in the field of education. While there are multicultural education policies, there is an urgency that they can reveal more, move forward and taken action, rather than merely realizing that there is a cultural diversity.

It is necessary to clarify the political and ideological dimensions which condition work and daily life in schools, an urgent task in a world in which meritocracy and the advancement of positivism in educational policies and research are completely covering the keys which explain the inequality and injustices in society and, consequently, in educational institutions (TORRES SANTOMÉ, 2013, p. 81).

In this sense, when we welcome multiculturalism ${ }^{3}$ and the policies stemming from this trend, we must consider whether or not the diverse cultural and social conditions of school subjects are contemplated in these conceptual approaches. Since in social relations there is the performance of the "antidifferentialist universalism which operates by the denial of differences and the differential

The term multiculturalism is outworn by its liberal and neo-liberal use, lacking the semantic, political, and practical force that interculturality has in the current postmodern and postcolonial context, especially in Latin America. Based on critical authors, Candau (2012), in "Critical Intercultural Didactic: approaches" brings the critical interculturality presented by Walsh (2009) which may have a dialogic contribution, through its epistemological and post-colonial analytical matrix, which in turn dialogues with Cultural Studies. 
universalism which operates by the absolutization of differences" (SANTOS, 2010, p. 283), it is vital to pay special attention to the approach of multiculturalism. Although this topic is widely present in educational legislation, and despite the struggle for the right to diversity in policies, there is still a great challenge for these to become curricular and social effective practices. This is because part of the educational policies that affirm diversity correspond to discourses linked to marketing logics, meritocratic and positivist interests. Such policies are, therefore, filled with intentions of universalization and cultural hegemony.

As a counterpoint to this logic and to attenuate the risk of this type of multiculturalist tendency, we opted for the position taken by Candau (2012), who considers "interculturalism as an approach that affects education in all its dimensions, favoring a critical and dynamic self-criticism, valuing reciprocal interaction and communication among different subjects and cultural groups" (p. 45). This is because, unlike multiculturalism, interculturalism has opened the debate about differences, identity, alterity, and social justice.

The perspective of critical interculturalism Walsh (2009), and also on the basis of post-critical theories ${ }^{4}$, we move toward an attempt of signification, translation and creation of educational policies, of curriculum ${ }^{5}$, and cultural policies which consider the leading role of the subjects of/in the school, so that there is the consideration and amplification of inter-places ${ }^{6}$, places of inclusion, favoring fair cultural negotiations in face of the identities and differences found in the school.

But, in addition to that, "to be democratic, political culture and cultural politics must not only accept differences, but also create conditions so that they can be lived in ambiguity" (GARCÍA CANCLINI, 2007, p. 116). The challenge is the coexistence of different identities and the acceptance that these cultural identities often hybridize. This requires a constant and democratic coexistence with the Other.

In this context, the school curriculum represents the space-time of negotiation of these cultural boundaries, as policies of separation, wall-building, and homogenization are also reflected in school settings.

\footnotetext{
${ }^{4}$ Silva (2014), Eyng (2010) understand that the post-critical curricular theory emphasizes the subjects' subjectivity its translations established in the cultural borders. This theory considers the new narratives or those that are disregarded in the relations of knowledge-power (EYNG, 2010).

5 Based on Silva (2014), Eyng (2010) presents the critical curriculum as a theory that is inserted in class struggles and liberation to the economic-capitalist model, located in the relations of power (EYNG, 2010).

6 According to Bhabha, the "inter-places" make different enunciations and subjectifications as opposed to subject and disorientation in the time and space of contemporaneity. "These 'inter-places' provide the ground for the elaboration of subjectivity strategies - singular or collective - that initiate new signs of identity and innovative positions of collaboration and contestation, in the sense of defining the very idea of society" (BHABHA, 2013, p. 20).
} 
The alignment of curricular approaches and paths to the assumptions of modernity continues to maintain a strong presence in school curricula, strengthening segregation strategies for the purposes of school culture homogenization and legitimation. Thus, narratives and practices of curricula whitewash different cultural groups, as "a strategy to not recognize their equal rights" (ARROYO, 2012, p. 126). However, "from those that are different come the most challenging questions for the political culture, pedagogical theories and equality policies [...]" (ARROYO, 2012, p. 126).

Pedagogies of homogenization eliminate rights, silence voices, and take the time of various collective entities, including religious ones. On the other hand, while "victims of historical processes of domination/subordination bring their pedagogies of resistance" into the school (ARROYO, 2012, p. 14), it cannot be assumed that all of these victims are conscious of or have overcome their weaknesses and can resist this domination outside of the places where they belong.

The same ideological imposition can be identified in curricula that curtail the rights of individuals from/within schools to demonstrate or place themselves in relation to their culture, especially their faith, in the case, for example, of Afro-Brazilian, indigenous, and Eastern religions.

Even if contemporary curricular policies include in their policy documents a transforming vision of education, conservative theories prevail in educational practices, as they maintain hierarchical relationships and disregard diversity. Therefore, the idea of a homogenizing education continues to be reinforced (EYNG, 2013).

In this sense, the contradictions between curricular policies and practices reflect the contradiction between the assumptions of the rigid modern thought on equality, which assumes a cultural hegemony, and the fluid modern or postmodern thought that defends the guarantee of right to cultural differences. The idea is not to reject equality, but to govern the differences that can be sublimated and deprived of their characteristics in the utilitarian approach to diversity.

Therefore, "new cultural and social identities emerge and are reinforced, erasing boundaries and transgressing prohibitions and identity taboos, in a time of delicious attitudes of crossing boundaries and the fascinating progress of hybridization of identities" (SILVA, 2010, p. 7). Thus, curricula have begun advocating multiple possibilities of identity trajectories, in contexts which are characterized by their diverse cultural systems. The right to equality and 
difference has been (re)designed in the dialogue between hegemonic and counter-hegemonic references, thus producing new possibilities for conceiving and expressing identity and diversity.

If understood as a trajectory of identity formation (SILVA, 2015), the curriculum is the appropriate place to guarantee the right to cultural diversity. The recognition and subsequent "expansion of diversity within the school space has also expanded the challenges related to the protection and guarantee of the right to equality and difference" (EYNG, 2013, p. 47).

Schools are important places for the inclusion of diversity and recognition of each individual as a producer of culture and the subject of history, with her or his human rights guaranteed. "Diversity is, in itself, conflicting, contradictory, and complex. The inclusion of education on human rights in the school curriculum appears as a possibility to mediate these conflicts and tensions" (EYNG, 2013, p. 47). Therefore, it is not an easy task to effectively guarantee the right to diversity, even when doing so it is translated into current policies. In school spaces, the challenges are constant. They require the construction, development, and practice of a curriculum that includes these aspects to promote the transition from assimilationist multiculturalism to effective and critical interculturality.

\section{Diversity in the curriculum in the perspective of religiosities}

In the contemporary context, identifying the set of culturally diverse traits of individuals and contexts is a major challenge. Doing so might generate conflict, but it can also be the source of new and powerful possibilities for dialogue.

The diversity incorporates multiple and complex traits, influences, manifestations, and possible identities. The school curriculum aims toward and is crossed by multiple orientations that characterize difference and configure identity, among which we pinch religiosity. A school curriculum is crossed by these multiple perspectives that characterize the difference and configure the identities. One of these perspectives is what we highlighted as religiosity. Establishing dialogues that respect and recognize diversity requires knowledge of the traits that constitute individual diversity as well as the traits of both local and global school contexts. To do so, first one must listen to the main subjects who give meaning to the curriculum to understand their perceptions and give them a voice. In this direction, thus, we bring students and teachers' voices together on a theme that 
has historically been a source of fierce dispute even in school curricula, although the purpose of religiosity is usually conciliation.

In Cultural Studies ${ }^{7}$, we can find different possibilities to analyze universalization and cultural hegemony, in order to consider the differences of cultures in contrast with rationalism and cultural binarism, especially those based on Western hegemony, articulating the cultural terrain as a field of ideological struggle, in which subjects and institutions act in the dispute of production and control of knowledge and meanings.

Therefore, Cultural Studies act like providential investigative interdisciplinary tools, and, why not, transdisciplinary tools for the reading of postmodern and postcolonial ${ }^{8}$ contingencies, having cultural identities and differences as relevant objects of study. That is why we chose Cultural Studies - as an operative concept in a path of complementarity with other concepts and knowledge, as a possibility for the subject to express his or her different "counter-hegemonic subjectivities and identities" (SILVA, 2005, p. 206). We understand that in the intercultural dialogue "[...] cultural differences touch each other in a 'contingent' and conflicting way, it becomes a moment of panic that reveals the frontier experience" (BHABHA, 2013,328 ) in which curricular hybrids are produced. Particularly, in this article, the experience we describe occurs at the boundaries of the school curriculum. This can be done through the interpretation of texts and intertexts, and of field research, in the analysis of the systems of signification present in cultures (SILVA, 2014) to recognize "other spaces of subaltern signification" (BHABHA, 2013, p. 26), such as religiosity, a field we have chosen to deepen the discussion about the right to diversity in daily curricula.

Due to the various possible statements, experiences and intentions that can be investigated in the daily life of schools, based on Cultural Studies, we can develop the following possibilities of observation and analysis:

\footnotetext{
7 Nowadays, Cultural Studies have poststructuralist and post-Marxist influence, especially with Stuart Hall, who was one of the main representatives of the Center for Contemporary Cultural Studies. The advance is felt and clear when we find objects of study such as: ideology, language and the symbolic in Cultural Studies, objects that, despite being found in Marxism (first theoretical basis of Cultural Studies), needed a re-reading from the questions postmodern ones. But as Hall (2009) states, it is important to keep in mind that Cultural Studies is an unfinished project and a continuous and renewable intellectual practice in order to facilitate the pattern of cultural differences in the game of subjects' identities.

8 Both Hall (2009) and Bhabha (2013) invoke postcolonialism through sociological and literary analyzes, respectively, not only with historical interests, but because they understand that this perspective presents, from the historical migrations and the new displacements, strong elements of social and cultural relations throughout the game of affirmations of identities and differences, which serves as the basis for Cultural Studies.
} 
The first possibility concerns studies that broaden the spectrum of the look at educational issues, performing analyses in various cultural spaces and instances, and inquiring about the possibility of thinking about a cultural curriculum. The second brings together surveys which focus on policies, programs, and government actions, asking, for example, about identities, subjects and forms of governance currently underway. Finally, the third brings together studies that question curricula from the identity conceptual operator and difference and, thus proceeding, challenge Eurocentric representations, inquire about the place of the differences seen from markers such as ethnicity, gender, race, sexuality and class (COSTA; WORTMANN; BONIN, 2016, p. 520).

In the case of this research, the methodology adopted the third approach in order to address the identity and the differences by the recognition of the religious manifestations in the curriculum in the description of how religiosity is considered by students and teachers ${ }^{9}$ in the scholarly daily life. After all, the research subjects are those who either express or not their religiosity in the school environment.

Therefore, the research presented here has as its starting point the cultures denied by the subjects in the disputed territory of the curriculum (SILVA, 2005), especially through representations of the religiosity by students and teachers, as some of the contingents that result from the relations of power and the colonization of knowledge.

In the field of education, Cultural Studies contribute to the evidence of four subfields (GIROUX, 1999). 1) Language: promotes conditions for the production of meanings and, by implication, produces knowledge which derives from the relations of power-knowledge (FOUCAULT, 1995). In this sense, the Cultural Studies are a reference to evaluate the disciplinary knowledge and other types of knowledge in the curriculum, considering its historical trajectories and political arrangements. 2) Culture as contested terrain in the curriculum: considering relations of power, class, race, gender, religion, among other categories, such as a critical look in opposition to the hegemony, the distinctions and the privilege of subjects and certain types of knowledge. 3) Differences: so that attention is paid to the subjectivities produced in individual and collective relations. 4) Pedagogy as culture: producing "knowledge, identities and desires" (p. 194) as pedagogical

It should be made clear that the research unrestrictedly respected the way the school approaches the theme in the curriculum, especially the confessional schools, making no judgment of values in relation to its practice. 
practices that give access to cultural boundaries and promote mediation in cultural productions and negotiations.

From the demarcation of these subfields, we adopted a qualitative approach, understanding that the school is an appropriate environment for the description and recognition of cultural differences, and particularly in this article, for the recognition of religious manifestations. In this movement, abstractions were constructed, understanding that the process is equally important, or even more so than the product and the result of the research (BOGDAN; BIKLEN, 1994). Therefore, in addition to the concern with the result, the research may provoke other important educational processes and displacements from the possible absences pointed out in the statements, the description and the data analysis.

The absences found in traditional curricula suffer from the emergency contraposition of critical and post-critical curriculum theories, which are our theoretical curricular options in this article, in an allusion to the absences and sociological emergencies ${ }^{10}$ of Santos (2010), that is, we want to recognize the experiences in the curriculum, as well as provoke new experiences with data analysis.

To understand how the investigated subjects express themselves on the subject of religiosity, the development of the research considered the field study in different school contexts. "These are places where subjects indulge in their daily tasks" (BOGDAN; BIKLEN, 1994, p. 113). For this, structured observation was practiced (VIANNA, 2007) in which data collection was performed in the second semester of 2016, in the form of an individual interview with teachers and in a collective manner in the classroom, with students.

In the approach to the students, we opted for the collective interview. The interviewer would introduce the theme and, as the questions were presented, the form was filled out individually, ensuring the respondents' privacy and freedom of expression. On the other hand, with the teachers we opted for individual interviews, considering the possibility of greater proximity to the subjects, without interfering in their perceptions, given the maturity of the group. The research project was submitted and approved by the research ethics committee, and the structured interviews were conducted with teachers and students. These meetings were previously planned, tested and reviewed. The scripts were organized containing the same

\footnotetext{
${ }^{10}$ According to Santos: "[...] the sociology of absences expands the domain of social experiences which are already available, the sociology of emergencies expands the domain of possible social experiences. The two sociologies are closely associated, since the more experiences are available today in the world the more experiences are possible in the future" (2010, p. 120).
} 
categories in the questions in order to allow dialogical approximation between the subjects, based on their perceptions about religiosity.

The curriculum subjects hearing was carried out in four high schools ${ }^{11}$, selected to represent each of the following modalities: 1 public school, 1 Catholic confessional school, 1 Evangelical confessional school and 1 private school. The option for high schools aimed at approaching students with greater definition in their positions on religiosity. In each school, students from two high school classes were heard, one class from the first grade and the other from the second grade from a total of 54 students. In the same schools, three to four teachers who teach the classes investigated from distinct areas of knowledge were interviewed, totaling 15 teachers.

The data presented unites the perceptions collected from four basic education schools in which 54 students, aged 14 to 18 , and 15 teachers, aged 29 to 46, were interviewed. The participating students comprised 17 (31.5\%) from the first year and $37(68.5 \%)$ from the second year of high school, while the teachers comprised $2(13.3 \%)$ who taught the first year, $3(13.3 \%)$ who taught the second year, and $10(66.7 \%)$ who taught both the first and second years of high school. There were 26 male (48.2\%) and 28 female (51.9\%) students, and 8 male $(53.3 \%)$ and 7 female $(46.7 \%)$ teachers. The interesting gender balance ensures a degree of equilibrium, at least in this aspect.

The central point of this research is to understand what religion and religiosity mean to young students and their teachers. To this end, we are going to present empirical and statement data on the religiosity of these individuals.

The responses gathered prompted elements for consideration and discussion in relation to youths' and teachers' religiosity in their daily lives at school, as an expression of diversity in the curriculum. The idea was to realize the first receptions of students and teachers on access to the theme of the sacred, through transcendental representation. In this case, "God" may serve as their source for the constitution of their religiosity.

We observed a strong transcendental quest for the image of God, which may show that, although history has observed a certain movement toward secularization (BERGER, 2001), especially in the post-advent of modernity, religion has

\footnotetext{
${ }^{11}$ However, the four schools took into account the scope of the research which was intended to reach different publics of students and teachers, also their socioeconomic characteristics, as well as to contemplate three different modalities of high school institutions.
} 
maintained its place in society and continues to find meaning in contemporary culture. In other words, our observations show a nostalgic search for the ultimate and unwavering fundamentals of religion (VATTIMO, 2000, p. 96).

This search is enhanced in the affiliation of individuals to a given religious institution, although it is possible that some answers do not necessarily represent active participation in these institutions; rather, their beliefs may go beyond the institutionalization of that faith or belief, in finding a difference between religiosity (subjectivity) and religion (objectivity). For Simmel (2009), religiosity is independent from religion, or even precedes it and helps to objectively engender it.

Regarding religious affiliation, there was a slight preponderance of Catholics among the respondents (teachers: $33.3 \%$; students: $42.6 \%$ ), followed by Protestants (teachers: $26.7 \%$; students: $37.0 \%$ ). This data follows the trend of official demographic statistics. On the other hand, it is important to note that, of the four schools surveyed, two were of Christian faith, which may have reinforced this numerical superiority.

In the reported perceptions of what religion comprises, two trends were identified in relation to faith/belief, one that considers religion in terms of "individual faith/belief" (students: $43.0 \%$; teachers: 12.5\%) and the other that considers it from the perspective of "group faith/belief," although the last one was present only among the students (18\%).

The rational and irrational relationship between manifestations of the sacred, which exists not only in the subjective but also in the objective world, in other words, in our everyday life (BERGER, 2001), implies a recognition that the supernatural is not merely a "rumor" (BERGER, 1997).

Just like religiosity, religion also promotes the integration of the subject to the world, considering its human contingencies, since it produces translations to give meaning to the existence of the subject, in this case in a more institutionalized way. Religions/churches are traditional associative methods of integration into the world, and are created by groups.

On the other hand, new forms of sociability and religiosity have emerged in the form of emotional communities (HERVIEU-LÉGER ${ }^{12}$ apud CIPRIANI, 2007) in which individuals re-organize their lives and search for the transcendental, thus overcoming the deadlock of secularization. This may also explain the participants'

12 HERVIEU-LÉGER, D. O peregrino e o convertido: a religião em movimento. Petrópolis: Vozes, 2008. 
responses in this study. "In this context, religion becomes a factor of choice in a society which emphasizes countless possibilities of choice, but reduces access and opportunities" (NOVAES, 2004, p. 328).

This concern is meaningful, as we have seen that in theorizing cultural diversity, its various differences are omitted, and religiosity might, in fact, be a difference. This expression of different groups and languages in the curriculum was evident in the subjects' manifestations, either institutionally or informally. All the schools presented religious experiences that dispute space and time in the curriculum, whether individually or in groups that claim spaces for their prayers. Therefore, there was the identification of assumptions related to the subfield of Cultural Studies referring to the curriculum as a contested field (GIROUX, 1999).

Conciliation in the territorial dispute in the curriculum may take place through dialogue. The data indicates the openness of students and teachers to inter-religious dialogue. Even though there is some prejudice against the religion of the others, it also reinforces curiosity, especially about those that are different. That is a possible sign of interculturality.

To analyze in greater depth the extent to which such an opening may occur, we asked "Are there conflicts in the school caused by faith or religion?" The responses were as follows: students (Yes: 27 [50\%]; No: 27 [50\%]); teachers (Yes: 6 [40\%]; No: $9[60 \%]$ ). In total, the responses were: Yes: $47.83 \%$; No: $52.17 \%$. The data is thus relatively equally distributed between Yes and No. As justification for the "Yes" reply, respondents were asked to indicate what the conflicts comprised.

Regarding the reasons given by those who responded "Yes," the most frequent response given by students $(29.17 \%)$, which also appeared in teachers' responses (40\%), was "talking/dialogue." This corroborates the trend of the responses regarding the opening to religiosity. On the other hand, $16.68 \%$ of students pointed out that "nothing had been done," which demonstrates the need to deepen how students and teachers are prepared for conflict mediation. Some other responses are as follows: "I think there is always a bit of religious intolerance, sometimes a conflict occurs, but nothing is done and it just stays between those involved." (Student 48); "Bad jokes and mainly with the least understood religions like Candomblé, Judaism, Umbanda, Buddhism, and others. There are jokes because of lack of understanding" (Student 30).

In general, this question is rather subjective, since "the cultural diversity within the school results in strained relationships which need appropriate mediation to 
create opportunities to experience a culture of recognition of differences and a culture of peace" (MOTA, 2015, p. 17617). At any rate, from the standpoint of Cultural Studies in Education (GIROUX, 1999), we can infer that these statements reinforce, although in a symbolic and not so explicit fashion, that there is an enhancement of the differences. Consequently, there is a dispute of certain intensity for space when it comes to religiosity.

The other question asked to justify Yes responses was: "Who was involved in the conflict and mediation?" The responses identified participating individuals from all representative segments of the school, with a preponderance of responses indicating the involvement of students and teachers. However, $33.33 \%$ of students indicated that only students were involved.

Tensions increased due to ignorance about the other, requiring mediation and dialogue based on an understanding of individuals' perceptions. In this sense, participants were asked about the contributions that understanding students' faith may have on the teacher's work.

The whole set of perceptions refers to fundamental assumptions in establishing dialogues which focus on the individuals' diversity, with emphasis on: the importance of respect (students: $47 \%$; teachers: $20 \%$ ); the importance of knowing each other (teachers: $33.4 \%$ ); knowledge and the need to minimize prejudice and discrimination, which constitute the source of the conflict (teachers: $20 \%$ ), and help in the planning and approach of the topic on the part of teachers. On the other hand, although in smaller percentages, expressions such as "religion has nothing to do with school," "we do not touch that subject," "you do not have to know it to respect it," "nothing changes if you know it," and "it does not interfere in the class," reflect a restricted vision of the curriculum and the complexity of issues that make up the diversity found in the school community.

According to Giroux (1999), in the perspective of Cultural Studies, pedagogy must favor cultural practices that promote good and fair cultural negotiations between students, between teachers and between students and teachers, as well as other possible relationships in the curriculum as a disputed territory. The goal is to produce new knowledge and access the cultural boundaries of daily school life.

The respondents' perceptions demonstrate the possibilities and limits to guaranteeing the right to diversity in the school curriculum. Based on aspects that may justify the need for interculturality to which their perceptions gave rise, we asked: "Is it possible to consider religious principles and values as a source of 
dialogue in school subjects and/or with other school skills?" Forty-three students responded Yes $(79.6 \%)$, while 11 responded No (20.4\%). Fourteen teachers responded Yes (93.3\%), while just one responded No (6.7\%). In total, $82.60 \%$ responded Yes while $17.39 \%$ responded No, thus indicating the potential for interculturality in the curriculum.

Justifications such as "dialogue between the varying knowledge," "helps explaining things/knowledge," and "there is religion in all areas of knowledge" strengthened the transversality of the theme of cultural diversity, in particular as expressed by religiosity. However, this occurred not only in positive justifications but also in those justifications that considered cultural and religious diversity. Nevertheless, the protection of ideals or beliefs may lead to violence or violations of the most diverse types. To the teacher or school as a whole, this poses a huge challenge, and it is necessary to consider the prevention, mediation, control, and elimination of these tensions and conflicts.

Furthermore, the relationships among equality, difference, and diversity need to be problematized and included in the curriculum, in order to avoid "the strength of a given speech about the curriculum and legitimizing the exclusion of other meanings" (MACEDO, 2013, p. 445). This set of perceptions points to the trend observed in previous studies, in which in teacher's education and practices there is usually a predominance of conservative, monocultural curricular approaches, "[...] with hegemonic preconceptions of standardization, so that teachers do not learn to dialogue with the different rationalities, different logics and to effect the dialogue with the plurality. "(EYNG et al., 2013, p.794).

This concern is meaningful, since we have observed that while theorizing on cultural diversity, many of its various differences have been omitted, one of which may be religiosity. However, the omission or invisibility of difference does not extinguish the intensity of its manifestations in terms of individuals and curricular contexts. "For these purposes to be effective, one of the fundamental conditions lies in the training and action of teachers as promoters of intercultural dialogue" (EYNG et al., 2013, p.784).

We found out, through the categories of analysis based on the Cultural Studies indicated by Giroux (1999): language, difference, curriculum as contested field and pedagogy as culture, that interculturality is the materialization of inter-places which can favor cultural negotiations, if they are mediated fairly. 


\section{Final considerations}

The recognition of cultures may cause a new politicization of school life and knowledge, as it turns the students' respective cultures into an equally important curriculum component. Thus, if students' religious beliefs produce knowledge and culture, they must be recognized as such in the curriculum.

The students and teachers' comments in this study indicate the imminent need for alterity in school as a means of overcoming prejudices and the difficulty involved in engaging in negotiation within the cultural boundaries of the school. Macedo (2006) signals the need to transcend such debate so that it does not reproduce a likely neoliberal intentionality to hide differences through the homogenization of the curriculum (WALSH, 2009).

Therefore, the idea is to break away from the formal and colonizing structures of knowledge in school and propose a decolonizing pedagogy of knowledge. It is not only a cultural diversity recognition project by itself, as some multiculturalist policies point out, but one of radical coexistence with each other and their ambiguities, of denaturalization of inequalities. In its ability to create alternative ways of thinking and producing new knowledge, this movement may engender a worldview that dialogues with what is different and values its historically achieved knowledge, as the Cultural Studies show us.

Once religious beliefs are understood to be an aspect of cultural diversity, critical interculturality may favor creating a place for such beliefs in this problematization. However, the opposite is also true; while religiosity may become a component of cultural diversity, it may also encourage interculturality when grounded in the curriculum through appropriate teaching.

Thus, we have critical interculturality as intent, critical intercultural didactics as a driver, and education on human rights as a political and epistemological source to give meaning to critical intercultural didactics in the curriculum.

Curricular policies and practices are the appropriate places to articulate the dialogue of the multiple knowledge bases of school individuals, including religious knowledge, in favor of education on human rights. This could comprise an intercultural teaching strategy which allows intentionality of critical interculturality to become effective (WALSH, 2009). Moreover, such knowledge is a relevant ethical source for the transformations that society so greatly requires. 
Intercultural curricular compositions allow us to break with diversity policies in which the other, the different, is seen as exotic, or a source of curiosity. In this case, politics takes on diversity views which have the intention, often veiled, of maintaining cultural hegemony, forging consensus attempts, which are no more than an illusory and imposed conciliation. Of course, it is not possible to escape the risk of divergences which may occur due to possible conflicts in the contact between differences. In other words, it is not enough to consider that there is a diversity of cultures, but rather it is necessary to dialogue with them and give them a leading role in the negotiation of cultural boundaries.

We reaffirm the need to establish new debates, with diversity as a human right to be understood and guaranteed in the curricular spaces. We also understand that Cultural Studies, through the categories of analysis chosen in this text, act in the mediation of dialogues which enable interculturality.

In summary, the challenge of implementing the right to diversity in the curriculum remains, and overcoming that challenge requires a fight for democratic principles and for an interculturality that is capable of promoting participation and recognition in the construction of a fair and equal society. In this direction, we have the Critical Interculturality (WALSH, 2009) as an accomplishment of this intentionality through conceptions and practices that favor fair cultural negotiations at the borders of the school curriculum. 


\section{O direito à diversidade na via da interculturalidade no currículo escolar}

\section{Resumo}

No presente texto, problematizamos o direito à diversidade no currículo, considerando-o como um percurso de constituição identitária e de garantia de direitos, mediante práticas que dialoguem com a igualdade e a diferença via interculturalidade. $O$ método dialético pauta o estabelecimento da relação dialógica entre traços de estudos teóricos, de políticas públicas e de percepções de sujeitos do currículo na perspectiva dos estudos culturais. Nesse intuito, trazemos as vozes de estudantes e de professores sobre um dos traços da diversidade, as religiosidades. Historicamente, trata-se de temática fonte de acirradas disputas, embora seus propósitos sejam de conciliação. Os resultados apontam a permanência do desafio da efetivação do direito à diversidade no currículo, cuja superação requer luta pelos princípios democráticos, pela via da interculturalidade capaz de promover a participação e o reconhecimento, da igualdade e da diferença. Portanto, a garantia do direito à diversidade requer a prática de uma pedagogia que favoreça o acesso às fronteiras no terreno contestado do currículo, por meio de negociações culturais justas.

Palavras-chave: Currículo. Diversidade cultural. Interculturalidade. Garantia de direitos. Educação Básica.

\section{El derecho a la diversidad en la via de la interculturalidad en el currículo escolar}

\section{Resumen}

En el presente texto, problematizamos el derecho a la diversidad en el currículo, considerándolo como trayecto de constitución identitaria y de garantía de derechos, mediante prácticas que dialoguen con la igualdad y la diferencia a través de la interculturalidad. El método dialéctico pauta el establecimiento de la relación dialógica entre trazos de estudios teóricos, de politicas públicas y de percepciones de sujetos del currículo en la perspectiva de los estudios culturales. En ese sentido, traemos las voces de estudiantes y profesores sobre uno de los rasgos de la diversidad, las religiosidades. Históricamente, se trata de temática fuente de fuertes disputas, aunque sus propósitos sean de conciliación. Los resultados apuntan a la permanencia del desafio de la efectividad del derecho a la diversidad en el currículo, cuya superación requiere lucha por los principios democráticos, por la vía de la interculturalidad capaz de promover la participación y el reconocimiento, de la igualdad y de la diferencia. Por lo tanto, la garantía del derecho a la diversidad requiere la práctica de una pedagogía que favorezca el acceso a las fronteras en el terreno cuestionado del currículo, a través de negociaciones culturales justas.

Palabras clave: Currículo. Diversidad cultural. Interculturalidad. Garantía de derechos. Educación Básica. 


\section{References}

ARROYO, M. G. Outros sujeitos, outras pedagogias. Petropólis: Vozes, 2012.

BERGER, P. L. Rumor de anjos: a sociedade moderna e a redescoberta do sobrenatural. 2. ed. Petropólis: Vozes, 1997.

BERGER, P. L. Dossel Sagrado: elementos para uma teoria sociológica da religião. 7. reimpr. São Paulo: Paulus, 2001.

BHABHA, H. K. O local da cultura. Belo Horizonte: Editora UFMG, 2013.

BOBBIO, N. A era dos direitos. 7. reimpr. Rio de Janeiro: Elsevier Brasil, 2004.

BOGDAN, R. C.; BIKLEN, S. K. Investigação qualitativa em educação: uma introdução à teoria e aos métodos. Porto: Porto Ed., 1994.

BONAVIDES, P. A quinta geração de direitos fundamentais. Revista Brasileira de Direitos Fundamentais e Justiça, n. 3, p. 82-83, 2008.

BRASIL. Comitê Nacional de Educação em Direitos Humanos. Plano nacional de educação em direitos humanos. Brasília, DF: Ministério da Justiça, SEDH : Ministério da Educação, 2007.

. Programa Nacional de Direitos Humanos (PNDH-3). Brasília, DF: Secretaria Especial dos Direitos Humanos da Presidência da República, 2010.

. Parecer CNE/CP n. 8 de 6 de março de 2012. Diretrizes Nacionais para a Educação em Direitos Humanos. Diário Oficial da União. Brasília, DF, 30 maio 2012. Seção 1, p. 33.

CANDAU, V. M. Sociedade multicultural e educação: tensões e desafios. In:__ (Org.). Didática crítica intercultural: aproximações. Petrópolis: Vozes, 2012. p. 19-54.

CIPRIANI, R. Manual de sociologia da religião. São Paulo: Paulus, 2007.

COSTA, M. V.; WORTMANN, M. L.; BONIN, I. T. Contribuições dos estudos culturais às pesquisas sobre currículo: uma revisão. Currículo sem fronteiras, v. 16, n. 3, p. 509-541, set./dez. 2016.

CULlETON, A.; BRAGATO, F. F.; FAJARDO, S. P. Perspectiva Histórica dos Direitos Humanos. In: . Curso de direitos humanos. São Leopoldo, RS: Unisinos, 2009. p. 27-42. 
ESTEVÃO, C. V. Direitos humanos, justiça social e educação pública: repensar a escola pública como um direito na era dos mercados. In: EYNG, A. M. (Org.). Direitos humanos e violência nas escolas: desafios e questões em diálogo. Curitiba: CRV, 2013.

EYNG, A. M. Currículo escolar. 2. ed. rev. atual. Curitiba: Intersaberes, 2010.

. Educação em Direitos Humanos no currículo escolar: o projeto político pedagógico como espaço de garantia ou violação de direitos. In: . (Org.). Direitos humanos e violência nas escolas: desafios e questões em diálogo. Curitiba: CRV, 2013. p. 29-58.

. et al. Diversidade e padronização nas políticas educacionais: configurações da convivência escolar. Ensaio: Avaliação de Políticas Públicas em Educação, v.21, n. 81, p. 773-800, out./dez. 2013. doi: http://dx.doi.org/10.1590/S0104-40362013000400007

FOUCAULT, M. O Sujeito e o Poder. In: RABINOW, P; DREYFUS, H. Michel Foucault: uma trajetória filosófica: para além do estruturalismo e da hermenêutica. Rio de Janeiro: Forense Universitária, 1995. p. 231-249.

GARCÍA CANCLINI, N. G. A globalização imaginada. São Paulo: Iluminuras, 2007.

GIROUX, H. A. Cruzando as fronteiras do discurso educacional: novas políticas em educação. Porto Alegre: Artmed, 1999.

HALL, S. Da diáspora: identidades e mediações culturais. Belo Horizonte: Ed. UFMG, 2009.

MACEDO, E. Currículo como espaço-tempo de fronteira cultural. Revista Brasileira de Educação, São Paulo, v. 11, n. 32, p. 285-296, 2006. doi: http://dx.doi.org/10.1590/S1413-24782006000200007

. A noção de crise e a legitimação de discursos curriculares. Currículo sem Fronteiras, v. 13, n. 3, p. 436-450, set./dez. 2013.

MOTA, G. L. Currículos e religiosidades: as manifestações religiosas como campo da diversidade cultural na escola. In: CONGRESSO NACIONAL DE EDUCAÇÃO (EDUCERE), 2015, 12. Anais... Curitiba: PUCPRess, 2015. p. 17613-17624. 
NOVAES, R. Os jovens "sem religião": ventos secularizantes, "espírito de época" e novos sincretismos: notas preliminares. Estudos avançados, v. 18, n. 52, p. 321330, 2004. doi: http://dx.doi.org/10.1590/S0103-40142004000300020

ORGANIZAÇÃO DAS NAÇÕES UNIDAS (ONU). Declaração Universal dos Direitos Humanos. Paris: ONU, 1948.

. Conferência Mundial dos Direitos Humanos: declarações e programas de ações de Viena. Viena: ONU, 1993.

ORGANIZAÇÃO DAS NAÇÕES UNIDAS PARA EDUCAÇÃO, CIÊNCIA E CULTURA (UNESCO). Convenção da UNESCO relativa à luta contra as discriminações na esfera do ensino. [S.1]: Unesco, 1960..

. Década da Educação em matéria de Direitos Humanos Genebra: ONU, 1994. Disponível em < http://direitoshumanos.gddc.pt/pdf/serie_ decada_1_b.pdf $>$. Acesso em 20 fev. 2017.

. Programa Mundial de Educação em Direitos Humanos: plano de ação: primeira fase. Brasília, DF: UNESCO / OHCHR, 2006. Disponível em: http://unesdoc.unesco.org/images/0014/001478/147853por.pdf. Acesso em: 20 fev. 2017.

SANTOS, B. S. A gramática do tempo: para uma nova cultura política. 3. ed. São Paulo: Cortez, 2010.

SILVA, T. T. (Org.). Alienígenas na sala de aula: uma introdução aos estudos culturais em educação. 6. ed. Petrópolis: Vozes, 2005.

. O currículo como fetiche: a poética e a política do texto curricular. 1. ed., 4. reimpr. Belo Horizonte: Autêntica, 2010.

. A produção social da identidade e da diferença. In: .; HALL, S.; WOODWARD, K. (Org.). Identidade e diferença: a perspectiva dos estudos culturais. Petrópolis: Vozes, 2014.

. Documentos de identidade: uma introdução às teorias de currículo. 3. ed. Belo Horizonte: Autêntica, 2015.

SIMMEL, G. Religião: Ensaios. São Paulo: Olho d'Água, 2009. v. 1.

TORRES SANTOMÉ, J. Currículo escolar e justiça social: o cavalo de troia da Educação. Porto Alegre: Penso, 2013. 
VEIGA-NETO, A. Cultura, culturas e educação.

Revista Brasileira de Educação. n. 23, p. 5-15, 2003.

doi: http://dx.doi.org/10.1590/S1413-24782003000200002

VIANNA, H. M. Pesquisa em educação: a observação. 22. ed. Brasília, DF: Liber Livro, 2007.

VATTIMO, G. O vestígio do vestígio. In: DERRIDA, J.; VATTIMO, G. (Org.). A religião: o seminário de Capri. São Paulo: Estação Liberdade, 2000. p. 91-107.

WALSH, C. Interculturalidade crítica e pedagogía de-colonial: in-surgir, re-existir e re-viver. In: CANDAU, V. M. F. (Org.). Educação Intercultural na América Latina: entre concepções, tensões e propostas. Rio de Janeiro: 7 Letras, 2009. p. 11-42.

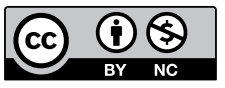

\section{Informações dos autores}

Ana Maria Eyng: Bolsista Produtividade CNPq, Doutora em Educação, professora e pesquisadora no Programa de Mestrado e Doutorado em Educação da Pontifícia Universidade Católica do Paraná PPGE/PUCPR. Contato: eyng.anamaria@gmail.com

Glaucio Luiz Mota: Mestre em Educação pelo Programa de Mestrado e Doutorado em Educação da Pontifícia Universidade Católica do Paraná PPGE/PUCPR, Assessor Educacional da Rede Marista de Solidariedade, Curitiba, Paraná-PR. Contato: glauciomota@hotmail.com

Mônica Luiza Simião Pinto: Mestre em Educação pelo Programa de Mestrado e Doutorado em Educação da Pontifícia Universidade Católica do Paraná PPGE/PUCPR, Curitiba, Paraná-PR. Técnica em Assuntos Educacionais - Instituto Federal do Paraná IFPR, Curitiba - Paraná-PR. Contato: monica.simiao82@gmail.com

Cleumir Sehn: Mestre em Educação no Programa de Mestrado e Doutorado em Educação da Pontifícia Universidade Católica do Paraná PPGE/PUCPR - Curitiba, PR. Diretor de escola de Ensino Fundamental. Prefeitura Municipal de Jaraguá do Sul, SC. Contato: cleusehn@gmail.com 